\title{
The effects of shearing and ascorbyl palmitate administration on physiological and blood metabolite profile of Padjadjaran sheep under heat exposure treatment
}

\author{
A.Taofik ${ }^{1}$, S. Bandiati ${ }^{2, *}$, A. M. Maskoen ${ }^{3}$ and M. Yusuf ${ }^{4}$ \\ ${ }^{1}$ Doctoral Program of Biotechnology, School of Postgraduate, Universitas Padjadjaran, \\ Jl. Dipati Ukur No 35 Bandung 40132 - Indonesia \\ ${ }^{2}$ Faculty of Animal Husbandry, Universitas Padjadjaran, \\ Jl. Raya Bandung Sumedang KM 21, Jatinangor 45363 - Indonesia \\ ${ }^{3}$ Laboratory of Molecular Genetics, Faculty of Medicine, Universitas Padjadjaran, \\ Jl. Jl. Eyckman No. 38 Bandung 40161 - Indonesia \\ ${ }^{4}$ Department of Chemistry, Faculty of Mathematics and Natural Sciences, Universitas Padjadjaran, \\ Jl. Jalan Raya Bandung-Sumedang Km. 21 Jatinangor Sumedang 4536 - Indonesia \\ *Corresponding E-mail: sri.bandiati@unpad.ac.id
}

Received August 04, 2020; Accepted January 18, 2021

\begin{abstract}
ABSTRAK
Ascorbyl-6-palmitate (AP) merupakan ester sintetik asam askorbat, telah digunakan sebagai pengawet makanan juga sebagai antioksidan pada kosmestik dan produk terkait lainnya. Penelitian bertujuan untuk mempelajari pengaruh pencukuran dan pemberian ascorbyl palmitate terhadap profil fisiologis domba Padjadjaran yang diberi cekaman panas. Profil fisiologis yang diamati adalah kecepatan respirasi (RR), denyut nadi (PR) dan temperature rektal (RT). Penelitian menggunakan 20 ekor domba Padjadjaran jantan berumur 1 - 1,5 tahun dengan bobot badan 25 hingga 47,5 $\mathrm{kg}$ yang diperoleh dari stasiun pembibitan di Purwakarta, Jawa Barat - Indonesia. Perlakuan yang dicobakan terdiri dari dua macam, (1) Pencukuran : tidak dicukur $\left(\mathrm{c}_{0}\right)$ dan dicukur $\left(\mathrm{c}_{1}\right)$; (2) Pemberian AP; tidak diberi $\left(\mathrm{a}_{0}\right)$ dan diberi $400 \mathrm{mg}$ AP $\left(\mathrm{a}_{1}\right)$; sehingga perlakuan keseluruhan adalah $\mathrm{a}_{0} \mathrm{c}_{0}, \mathrm{a}_{0} \mathrm{c}_{1}, \mathrm{a}_{1} \mathrm{c}_{0}$ dan $\mathrm{a}_{1} \mathrm{c}_{1}$. Cekaman panas diberikan dengan cara penjemuran domba saat temperatur lingkungan mencapai $34^{\circ} \mathrm{C}, 3$ jam sehari, 3 hari dalam seminggu. Saat dijemur, setiap domba ditambatkan. Hasil penelitian menunjukkan bahwa pemberian AP dan pencukuran memberikan pengaruh interaksi terhadap frekuensi pernafasan, denyut nadi dan temperatur rektal. Konsentrasi glukosa dan cholesterol dipengaruhi oleh interaksi penambahan AP dengan pencukuran. Disimpulkan bahwa penambahan AP dan pencukuran mengurangi pengaruh negatif cekaman panas berdasarkan profil fisiologis dan metabolit darah domba Padjadjaran. Pencukuran disarankan dilakukan secara berkala.
\end{abstract}

Kata kunci : Ascorbyl palmitate, cekaman panas, domba, pencukuran

\begin{abstract}
Ascorbyl-6-palmitate (AP) was a lipid-soluble synthetic ester of ascorbic acid that has been used as a preservation agent for foods and as an antioxidant in cosmetics and related products. This study aims to investigate the effect of shearing management and ascorbyl palmitate administration on physiological and hematological profiles in under heat load Padjadjaran sheep. The physiological profile involves respiration rate (RR), Pulse rate (PR), and rectal temperature (RT). Twenty rams Padjadjaran 1 - 1,5-
\end{abstract}


year-old, weighing between 25 to $47.5 \mathrm{~kg}$ used from sheep breeding station Purwakarta, West Java Indonesia. There are two treatments level in this research, (1). Shearing divide into two groups, unshearing $\left(\mathrm{c}_{0}\right)$ and shearing $\left(\mathrm{c}_{1}\right)$; (2). AP administration also divides two groups, not given $\left(\mathrm{a}_{0}\right)$ and given $400 \mathrm{mg}$ each head daily $\left(a_{1}\right)$. The whole treatments were $\mathrm{a}_{0} \mathrm{c}_{0}, \mathrm{a}_{0} \mathrm{c}_{1}, \mathrm{a}_{1} \mathrm{c}_{0}$ and $\mathrm{a}_{1} \mathrm{c}_{1}$. Heat exposure application was exposed to sunlight when the sheep exposed, the animal tethered by rope at the neck region. The sheep exposed to the sun when the ambient temperature at least $34^{\circ} \mathrm{C}, 180$ minutes each day, three days a week. The result showed that AP administration and shearing have interaction effects on RR, PR and RT. The level of glucose and total protein is affected by interaction effect of AP administration and shearing, while cholesterol affected to shearing. The conclusion, supplementing AP and shearing application could reduce the negative impact of heat stress on physiological and blood metabolite profiles of Padjadjaran sheep. Although the wool of local breed has not economic value, the shearing is regularly needed.

Keywords: Ascorbyl palmitate, heat stress, shearing, sheep

\section{INTRODUCTION}

Indonesia has high both ambient temperatures and solar radiation during the year. This condition was a limiting factor and unfavorable for livestock covered with thick hair like sheep. Hair was one of the inhibitors of sheep's heat dissipation and has the potential to cause heat stress. In Indonesia, the sheep farmer has not been done shearing regularly because the local sheep are not the type of producing wool which economic-value. Hair is one of the inhibitors of sheep's heat dissipation and has the potential to cause heat stress. Shearing increases the heat exchange between the body of the animal to the environment so that the release of heat without compensation for heat production (Aleksiev, 2008). The traits of animal behavior are early indicators of adaptation and response to environmental alterations ((De et al., 2017). The previous researcher reported that heat stress affects some metabolite concentrations of blood such as glucose, cholesterol, and total protein.

L-ascorbic acid (vitamin C) was an antioxidant that high solubility in water, so it was easily degraded, very sensitive to Oxygen, light, and heat (Dong and Wang, 2016). Ascorbyl-6palmitate (AP) was a lipid-soluble synthetic ester of ascorbic acid. AP has been used as an antioxidant in cosmetics and related products (Austria et al., 1997). Food and Drug Administration (FDA) status of AP acknowledged as safe due to the apparent lack of known toxicity. There was a rising interest in possible beneficial effects of AP, linked mostly to its antioxidant capacity, in various areas of research, including to animals.

The objective of this research was to investigate the shearing management and AP supplementation in the control of heat stress in Padjadjaran sheep.

\section{MATERIALS AND METHODS}

\section{Animals and Feeding Management}

Twenty rams Padjadjaran 1 - 1,5-year-old, weighing between 25 to $47.5 \mathrm{~kg}$ used in the present study came from sheep breeding station at Purwakarta - West Java - Indonesia. The animal was offered a mixture of concentrates $(30 \%)$ and forages $(70 \%)$ as much as $3.5 \%$ dry matter of body weight. The concentrates feed has $13 \%$ of protein and $65-70 \%$ Total Digestible Nutrient (TDN). Drinking water serves an ad-libitum

\section{Chemicals}

Ascorbyl-6-palmitate $(99.9 \%$ pure $)$ was purchased from Shandong Zhi Shang Chemical Co.Ltd, China.

\section{Experimental Procedure}

The study was conducted based on experimental methods designed Factorial Randomized Block Design. There were two treatments level in this research, (1) shearing divide two-class, un-shearing $\left(\mathrm{c}_{0}\right)$ and shearing $\left(\mathrm{c}_{1}\right)$; (2) AP administration also divides two-class, not given $\left(\mathrm{a}_{0}\right)$ and given $400 \mathrm{mg}$ each head daily $\left(a_{1}\right)$. The whole treatments were $a_{0} c_{0}, a_{0} c_{1}, a_{1} c_{0}$ and $\mathrm{a}_{1} \mathrm{c}_{1}$. Heat shock application was exposed to sunlight. When the sheep were exposed, the animal tethered by rope at the neck region. The sheep exposure to the sun when the ambient temperature at least $34^{\circ} \mathrm{C}$.

Heat exposure procedure. Equipment and procedure of heat exposure modified from Indu et al 2015. All animals entered into a simple chamber made from bamboo and wood, size 150 
x $100 \times 100 \mathrm{~cm}$ in length, width, and tall, respectively. Each chamber filled in 5 rams appropriate to treatment. The duration of heat expose was 180 mins per day, three days a week.

Blood collection. Collecting blood done every week after heat exposure application. Blood was collected by venipuncture using vacutainer tubes with EDTA from vena jugularis. Separated blood plasm use centrifuge at $3500 \mathrm{rpm}$ for 10 minutes, the plasm entered to Eppendorf tube, stored at $-20^{\circ} \mathrm{C}$ until analysis (Indu et al., 2015).

\section{Parameters}

Respiration rate. The respiration rate was recorded by counting flank movements per minute from a non-obstructive distance (Al-Azzawi et al., 2017).

Pulse Rate. The pulse rate was measured by a modification of Al-Azzawi et al. (2017) fingered the pulses of the vena femoralis for one minute.

Rectal Temperature. Rectal temperature measured by inserting a digital thermometer into the rectum as deep as $3 \mathrm{~cm}$, hold it until makes a beep (Al-Azzawi et al., 2017).

Blood Metabolite. The blood determine were total protein, glucose and cholesterol. The examination of all variables using spectrophotometer method with reagent kit produced DiaSys (according to manufacturer's instructions of DiaSys System GmbH, Holzheim, Germany).

Statistical Analysis. The obtain data which included both physiological blood metabolites were analyzed by ANOVA (Steel and Torrie, 1997). Data calculated using Minitab software. The level of significance was set at $\mathrm{P}<0.05$.

\section{Ethical Approval}

All rams were maintained under standard environmental conditions with ad libitum feed and water. The animals were treated humanely during the whole period of the experimental study, and the work was considered by the institutional Research Ethics Committee Padjadjaran University No. 1157/UN6.KEP/EC/2019 on ethical standards in animal experimentation.

\section{RESULTS}

\section{Environmental condition}

The site of research was located at the Laboratory of Animal Breeding and Biometric Animal Husbandry Faculty - Padjadjaran
University ( $6^{\circ} \quad 55^{\prime} 23.2$ "S $\left.107^{\circ} 46^{\prime} 12.2^{\prime \prime E}\right)$. The range of temperature minimum in housing is 20.9 $-23.2^{\circ} \mathrm{C}$, and a maximum $29.2-33.5^{\circ} \mathrm{C}$. The range of minimum relative humidity $44-65 \%$ and a maximum of 78 - 99\%. Environmental condition measure by digital thermo-hygrometer.

\section{Physiological Profiles}

Physiological profiles, respiration rate (RR), pulse rate (PR), and rectal temperature (RT) before and after heat shock application present in Table 1.

The RR before heat exposure around the normal range $25.13 \pm 6.93$ to $39.60 \pm 24.79$ breath per minute. ANOVA showed that shorn has a significant effect $(\mathrm{P}<0.05)$ on $\mathrm{RR}$ in the first and second weeks after heat shock, while AP administration in the sixth week. In the fifth week, AP and shearing have an interaction effect on RR. Shearing treatment has a positive effect (low) to RR. Treatment $a_{1} c_{1}$ tends a positive effect on RR. In fifth-week, combination of AP administration and shearing $\left(a_{1} c_{1}\right)$ leads to sheep able to control heat stress at a high level, other treatment at a heavy level. It indicates these factors' synergism to control heat stress.

According to the scale stress level developed by (Silanikove 2000b), the stress level in this research is presented in Table 2. Before heat shock, about $85 \%, 5 \%$, and $10 \%$ of animal in no stress condition, low level, and medium-high stress level, respectively. Until the sixth-week heat shock, the animal stress level increase, from $1^{\text {st }}$ week until $5^{\text {th }}$ week, $25 \%, 30 \%, 20 \%, 15 \%$, and $15 \%$ ram status in no stress.

The pulse rate range before heat load application is $53.86 \pm 4.78$ to $56.8 \pm 1.40$ beats per minute. ANOVA showed that in the second week, unshorn able to control pulse rate $(\mathrm{P}<0.05)$, and in the fourth and sixth-week measurement occur an interaction $(\mathrm{P}<0.05)$ between shearing and $\mathrm{AP}$ administration.

Before heat shock, the average rectal temperature $38.4-38.54^{\circ} \mathrm{C}$. Variation above and below normal is a measure of the animal's ability to resist environmental stress factors. Until the fourth week and sixth week, AP and shearing no significant effect on rectal temperature. A fifth week AP and shearing interact to affect rectal temperature, without combination effect of AP and shearing (only shear or only $\mathrm{AP}, \mathrm{a} 1 \mathrm{c} 0$ and a0c1) have a good effect on rectal temperature. 


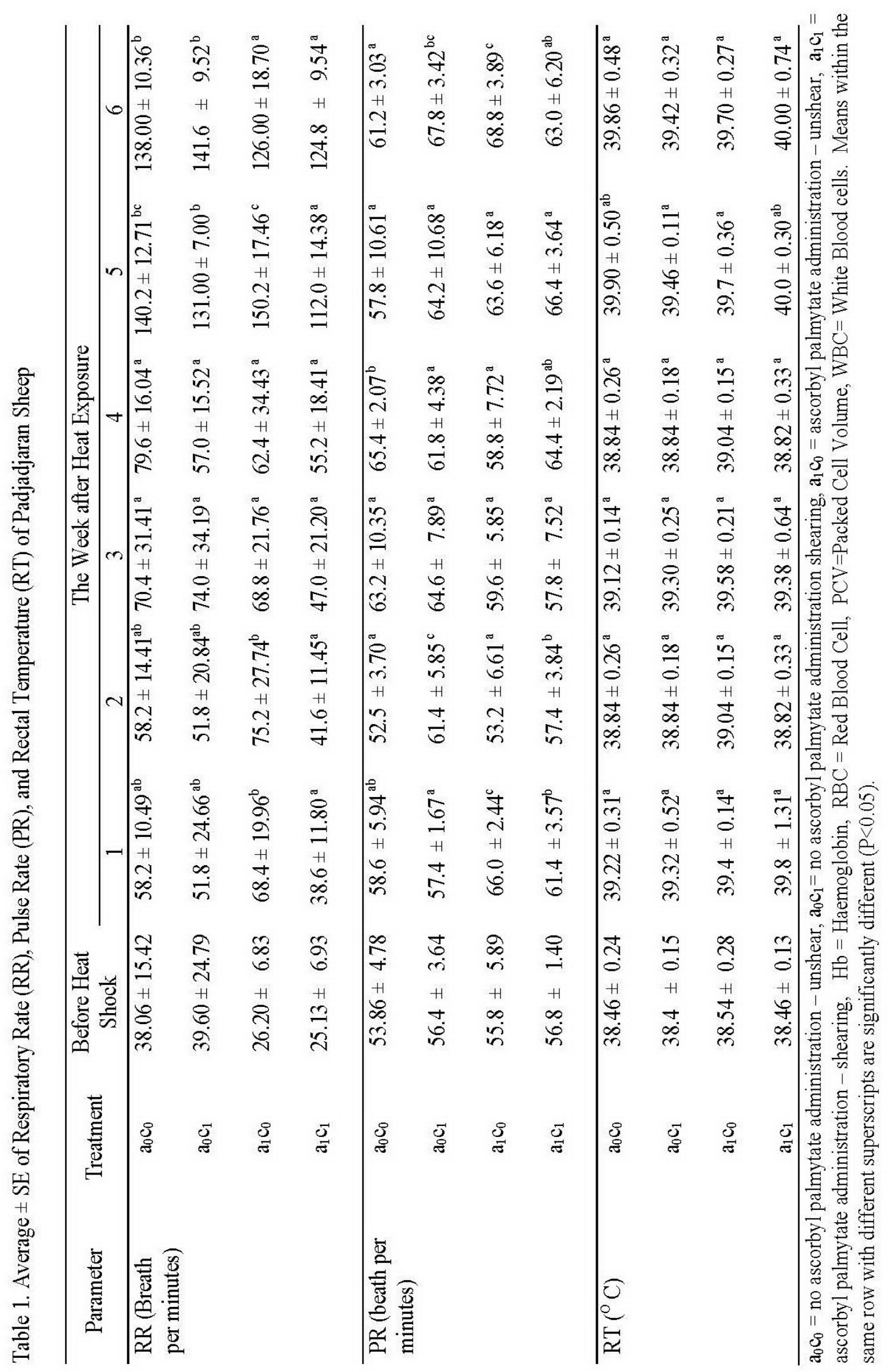


Table 2. The Stress Level in Padjadjaran Sheep

\begin{tabular}{|c|c|c|c|c|c|c|c|c|}
\hline \multirow{2}{*}{ Respiration Rate } & \multirow{2}{*}{ Stress Level } & \multirow{2}{*}{$\begin{array}{c}\text { Before } \\
\text { Heat } \\
\text { Shock }\end{array}$} & \multicolumn{6}{|c|}{ Week } \\
\hline & & & 1 & 2 & 3 & 4 & 5 & 6 \\
\hline & & \multicolumn{7}{|c|}{ 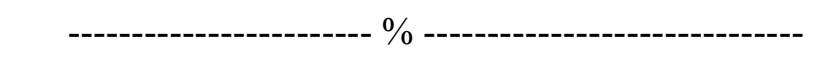 } \\
\hline$<40$ breaths $/ \min ^{1}$ ) & No stress & 85 & 25 & 30 & 20 & 15 & 15 & 0 \\
\hline $40-60$ breaths $/ \min ^{1}$ ) & Low & 5 & 40 & 40 & 40 & 45 & 35 & 0 \\
\hline $61-80$ breaths $/ \min ^{1}$ ) & Medium - high & 10 & 20 & 20 & 20 & 20 & 35 & 0 \\
\hline $81-120$ breaths $/ \min ^{1}$ ) & High & 0 & 15 & 10 & 5 & 5 & 10 & 25 \\
\hline $121-200$ breaths $/ \min ^{2}$ ) & Heavy & 0 & 0 & 0 & 15 & 15 & 5 & 75 \\
\hline$>200$ breaths $/ \min ^{1}$ ) & Severe & 0 & 0 & 0 & 0 & 0 & 0 & 0 \\
\hline
\end{tabular}

${ }^{1}$ Scale adapted from Silanikove (Silanikove, 2000)

${ }^{2}$ Own study

\section{Blood Metabolite Profile}

Blood metabolite profiles, glucose, cholesterol, and total protein present in Table 3. According to the average value, antioxidant AP affect glucose concentration $(\mathrm{P}<0.05)$. In the third and fourth week, no significant effect of treatment on glucose. In the fifth week antioxidant effect $(\mathrm{P}<0.05)$ to glucose, while in the sixth week there is an interaction effect $(\mathrm{P}<0.05)$ to glucose.

Shearing generally affect cholesterol, in third week glucose affect antioxidant, while shearing affect glucose in the fourth week. In the fifth and sixth week, no significant effect of treatment on glucose.

According to the average, shearing and AP administration no different effect on total protein. Both in the third and fourth week, shearing has significance to total protein, in the fifth week there are interaction effects of treatment on total protein; in the sixth week total protein no affected by treatment.

\section{DISCUSSION}

In sheep, the RR normal 25 - 30 breath per minute (Indu et al., 2014; Veerasamy Sejian et al., 2010). RR was an indicator of heat load and heat stress in animals (Okourwa, 2015). RR before heat exposure in current research classified no stress. McManus et al. (2016) stated that according to RR, there was heat stress level classification, no stress: up to 40 breath per minutes, low stress: $40-60$; middle stress: $61-$
80; high stress: $81-120$, very high stress: $121-$ 193, and severe heat stress: more than 193 breath per minutes. Increasing RR showed that animals endeavor to the maintenance of normal body temperature in a way increasing heat exhausting through breath evaporation (Shaji et al., 2017). When heat shock at $28.95^{\circ} \mathrm{C}, \mathrm{RR}$ of shorn and unshorn of sheep no significantly different (Taha et al., 2018). Higher RR is a physiological response to increasing oxygen delivery to the lungs, which could improve heat production and, subsequently, elevate body temperature (Habibu et al., 2017).

In sheep farming, shearing was a routine activity, helpful thermogenesis inductor (AlRamamneh et al., 2011). Shearing effect on the oxidative parameter and change the homeostasis balance (Piccione et al., 2011). In the sixth week, APs significant effect $(\mathrm{P}<0.05)$ decrease $\mathrm{RR}$ compared to non-AP.

The previous study stated that range pulse rate in sheep 98.5 - 103,6 pulse per minutes (Seixas et al., 2017), 70 - 80 pulses per minutes and increase to 83 pulses when exposing to heat load (Al-Haidary et al., 2012), 90 - 107 pulses (Wojtas et al., 2014). Another researcher report in the $15^{\text {th }}$ first day after shearing, the pulse rate significantly increase, then decrease gradually (Casella et al., 2016). However, in the first week, the pulse rate in non-AP administration treatment lower than administration AP, which means that in case AP does not need yet to control heat stress, reinforce by RR in this session categorized as low 
Table 3. Average \pm SE of Glucose. Cholesterol and Total Protein of Padjadjaran Sheep

\begin{tabular}{rcrrrl}
\hline Treatment & \multicolumn{4}{c}{ Week after Heat Exposure } & \multirow{2}{*}{ Average } \\
\cline { 2 - 4 } & \multicolumn{1}{c}{$3^{\text {rd }}$} & $4^{\text {th }}$ & $5^{\text {th }}$ & \multicolumn{1}{c}{$6^{\text {th }}$} & \\
\hline Glucose & & & & \\
$\mathrm{a}_{0} \mathrm{c}_{0}$ & $66.85 \pm 7.54^{\mathrm{ns}}$ & $62.29 \pm 13.18^{\mathrm{ns}}$ & $99.21 \pm 30.05^{\mathrm{b}}$ & $70.22 \pm 13.11^{\mathrm{b}}$ & $74.64 \pm 7.55^{\mathrm{b}}$ \\
$\mathrm{a}_{0} \mathrm{c}_{1}$ & $53.35 \pm 5.38^{\mathrm{ns}}$ & $63.34 \pm 5.79^{\mathrm{ns}}$ & $96.61 \pm 54.48^{\mathrm{b}}$ & $140.22 \pm 93.01^{\mathrm{c}}$ & $83.06 \pm 31.32^{\mathrm{b}}$ \\
$\mathrm{a}_{1} \mathrm{c}_{0}$ & $44.01 \pm 30.29^{\mathrm{ns}}$ & $56.56 \pm 6.99^{\mathrm{ns}}$ & $53.37 \pm 13.23^{\mathrm{a}}$ & $63.04 \pm 12.85^{\mathrm{ab}}$ & $62.97 \pm 21.78^{\mathrm{a}}$ \\
$\mathrm{a}_{1} \mathrm{c}_{1}$ & $57.45 \pm 34.28^{\mathrm{ns}}$ & $57.6 \pm 6.06^{\mathrm{ns}}$ & $46.90 \pm 9.38^{\mathrm{a}}$ & $54.19 \pm 24.23^{\mathrm{a}}$ & $52.82 \pm 14.81^{\mathrm{a}}$
\end{tabular}

Cholesterol

$\begin{array}{lrrrrr}\mathrm{a}_{0} \mathrm{c}_{0} & 243.38 \pm 103.34^{\mathrm{b}} & 97.58 \pm 89.91^{\mathrm{a}} & 113.95 \pm 46.60^{\mathrm{ns}} & 97.60 \pm 39.38^{\mathrm{ns}} & 135.21 \pm 48.48^{\mathrm{a}} \\ \mathrm{a}_{0} \mathrm{c}_{1} & 246.03 \pm 117.22^{\mathrm{b}} & 207.11 \pm 102.81^{\mathrm{b}} & 106.09 \pm 34.98^{\mathrm{ns}} & 94.69 \pm 13.73^{\mathrm{ns}} & 153.13 \pm 37.8^{\mathrm{b}} \\ \mathrm{a}_{1} \mathrm{c}_{0} & 102.49 \pm 43.19^{\mathrm{a}} & 108.38 \pm 21.93^{\mathrm{a}} & 83.17 \pm 22.69^{\mathrm{ns}} & 98.84 \pm 37.32^{\mathrm{ns}} & 98.22 \pm 10.50^{\mathrm{a}} \\ \mathrm{a}_{1} \mathrm{c}_{1} & 97.35 \pm 20.86^{\mathrm{a}} & 126.31 \pm 19.52^{\mathrm{b}} & 139.87 \pm 33.45^{\mathrm{ns}} & 98.77 \pm 26.33^{\text {ns }} & 110.75 \pm 17.44^{\mathrm{b}}\end{array}$

Total Protein

\begin{tabular}{llllll}
$\mathrm{a}_{0} \mathrm{c}_{0}$ & $4.25 \pm 1.33^{\mathrm{a}}$ & $6.48 \pm 1.02^{\mathrm{b}}$ & $7.01 \pm 0.76^{\mathrm{b}}$ & $5.59 \pm 0.64^{\mathrm{ns}}$ & $5.79 \pm 0.38^{\mathrm{ns}}$ \\
$\mathrm{a}_{0} \mathrm{c}_{1}$ & $6.10 \pm 0.48^{\mathrm{b}}$ & $6.21 \pm 0.34^{\mathrm{a}}$ & $5.38 \pm 0.52^{\mathrm{a}}$ & $5.63 \pm 0.63^{\mathrm{ns}}$ & $5.83 \pm 0.43^{\mathrm{ns}}$ \\
$\mathrm{a}_{1} \mathrm{c}_{0}$ & $4.29 \pm 0.74^{\mathrm{a}}$ & $5.17 \pm 1.31^{\mathrm{b}}$ & $5.21 \pm 0.54^{\mathrm{a}}$ & $5.07 \pm 2.28^{\mathrm{ns}}$ & $5.08 \pm 1.03^{\mathrm{ns}}$ \\
$\mathrm{a}_{1} \mathrm{c}_{1}$ & $5.45 \pm 0.55^{\mathrm{b}}$ & $3.07 \pm 2.63^{\mathrm{a}}$ & $7.39 \pm 0.52^{\mathrm{b}}$ & $5.29 \pm 1.22^{\mathrm{ns}}$ & $5.47 \pm 0.96^{\mathrm{ns}}$ \\
\hline
\end{tabular}

$\mathrm{a}_{0} \mathrm{c}_{0}=$ no ascorbyl palmytate administration - unshear, $\mathrm{a}_{0} \mathrm{c}_{1}=$ no ascorbyl palmytate administration shearing, $\mathrm{a}_{1} \mathrm{c}_{0}=$ ascorbyl palmytate administration - unshear, $\mathrm{a}_{1} \mathrm{c}_{1}==$ ascorbyl palmytate administration - shearing. Means within the same row with different superscripts are significantly different $(\mathrm{P}<0.05)$.

heat stress. The higher PR in the stressed animals dissipate more heat to its surroundings by increasing the blood flow to their body surfaces (Shaji et al., 2017).

Rectal temperature is an indicator of heat storage in an animal's body and usually be used to assess the adversity of the thermal environment (Ganaie et al., 2013). Rectal temperature, respiration rate, and heart rate reflect the degree of stress imposed on animals (Ganaie et al., 2013). Antioxidant administration no effect on RT (Chauhan et al., 2014), a combination of minerals and vitamin E (Sejian et al., 2014), melatonin application (Bouroutzika et al., 2020) may reduce RT, dose $100 \mathrm{mg} \mathrm{kg}^{-1}$ body weight in goat able to control heat stress. Vitamin $\mathrm{C}$ administration in $500 \mathrm{mg} / \mathrm{kg}$ feed highly significant decrease in $R R$ and $P R$, but no significant effect on TR (Al-Azzawi et al., 2017). Ascorbic acid supplementation 50 and $100 \mathrm{mg} / \mathrm{kg}$ body weight significantly decrease RR, PR and RT compare to control without supplementation (Khan and Konwar, 2015).

Compared to previous research, the glucose, cholesterol and total protein concentration grazed sheep are $43.25 \pm 1.36 \mathrm{mg} / \mathrm{dL}, 56.64 \pm 1.68 \mathrm{mg} / \mathrm{dL}$ and $7.14 \pm 0.12 \mathrm{~g} / \mathrm{dL}$ respectively (Badakhshan and Mirmahmoudi, 2016). Glucose and cholesterol concentration of sheep supplemented curcumin $900 \mathrm{mg}$ per sheep, housed at $33.32^{\circ} \mathrm{C}$ are 3.81 and $3.3 \mathrm{mmol} / \mathrm{L}$ respectively (Jiang et al., 2019). Glucose, cholesterol and total protein concentration of lambs which free access to water lower than limited access (Vosooghi-Postindoz et al., 2018). Singh et al. (2016) report that the total protein concentration of Indian indigenous sheep 
at heat stress condition higher than normal, while cholesterol and glucose concentration oppositely. In goat during summer, ascorbic acid supplementation 50 and $100 \mathrm{mg} / \mathrm{kg}$ body weight significantly increase plasma total protein compare to $0 \mathrm{mg}$, while on glucose no difference (Khan and Konwar, 2015). In current study, during heat exposure application, sheep tethered, they are no chance to escape to shady.

\section{CONCLUSION}

It could be concluded, supplementing AP and shearing application could reduce the negative impact of heat stress on physiological and blood metabolite profiles of Padjadjaran sheep. Although the wool of local breed has not economic value, the shearing regularly needed.

\section{ACKNOWLEDGMENTS}

The authors would like to thank you for financial supporting from Program Riset Desertasi Doktor - Direktorat Jenderal Pendidikan Tinggi and Academic Leadership Grand (ALG) Unpad (Contract No. 2413/UNG.J/LT/2019).

\section{REFERENCES}

Al-Azzawi, S. H., R.I. Khalil, and Z.I. Mohammed. 2017. Effect of Vitamin C Administration on Heat Tolerance of Local and Turkish Awassi Sheep in Diyala Province of Iraq. Bas. J. Vet. Res., 16(1):288-297.

Al-Haidary, A. A., R.S. Aljumaah, M.A. Alshaikh, K.A. Abdoun, E.M. Samara, A.B. Okab, and M.M. Alfuraiji. 2012. Thermoregulatory and physiological responses of Najdi sheep exposed to environmental heat load prevailing in Saudi Arabia. Pak. Vet. J. 32(4):515-519.

Al-Ramamneh, D., M. Gerken, and A. Riek. 2011. Effect of shearing on water turnover and thermobiological variables in Gierman Blackhead mutton sheep. J, Anim. Sci, 89(2):4294-4304.

Aleksiev, Y. 2008. Effect of Shearing on Some Physiological Responses in Lactating Ewes Kept Indoor. Bulg. J. Agric. Sci. 14(4):417423.

Austria, R., A. Semenzato and A. Bettero. 1997. Stability of vitamin $\mathrm{C}$ derivatives in solution and topical formulations. J. Pharm. Biomed.
15(6):795-801.

Badakhshan, Y. and R. Mirmahmoudi. 2016. Blood metabolites of one-humped camel (Camelus dromedarius) versus sheep during summer heat stress. Iran J. Vet. Med. 10(1):65-71.

Bouroutzika, E., D. Kouretas, S. Papadopoulos, A.S. Veskoukis, E. Theodosiadou, S. Makri, C. Paliouras, M.L. Michailidis, M. Caroprese, and I. Valasi. 2020. Effects of melatonin administration to pregnant ewes under heat-stress conditions, in redox status and reproductive outcome. Antioxidants. 9(3):266.

Casella, S., E. Giudice, A. Passantino, A. Zumbo, S. Di Pietro, and G. Piccione. 2016. Shearing induces secondary biomarkers responses of thermal stress in sheep. Anim. Sci. Pap. Rep. 3491):73-80.

Chauhan, S. S., P. Celi, E. N. Ponnampalam, B.J. Leury, F. Liu, and F.R. Dunshea. 2014. Antioxidant dynamics in the live animal and implications for ruminant health and product (meat/milk) quality: Role of vitamin $E$ and selenium. Anim. Prod. Sci. 54(10):1525-1536.

De, K., D. Kumar, V.K. Saxena, P. Thirumurugan, and S.M.K. Naqvi. 2017. Effect of high ambient temperature on behavior of sheep under semi-arid tropical environment. Int. J. Biometeorol. 61(7):1269-1277.

Dong, F., and Y. Wang. 2016. Encapsulation of Vitamin C by A Double- Layer Zein / Chitosan Structure with Improved. Int. J. Nanomedicine 2(1)1-7.

Ganaie, A. H., G. Shanker, N.A. Bumla, R.S. Ghasura, N.A. Mir, W. Sa, and G.B. Dudhatra 2013. Biochemical and Physiological Changes during Thermal Stress in Bovines. J. Vet. Sci. Technol. 4(1):1-6.

Habibu, B., M.U. Kawu, T. Aluwong, and H.J. Makun. 2017. Influence of seasonal changes on physiological variables, haematology and serum thyroid hormones profile in male Red Sokoto and Sahel goats. J. Appl. Anim. Res. 45(1):508-516.

Indu, S., V. Sejian, and S.M.K. Naqvi. 2014. Impact of simulated heat stress on growth, physiological adaptability, blood metabolites and endocrine responses in Malpura ewes under semiarid tropical environment. Anim. Prod. Sci. 55(6):766776. 
Jiang, Z., Y. Wan, P. Li, Y. Xue, W. Cui, Q. Chen, and J. Chen. 2019. Effect of Curcumin Supplement in Summer Diet on Blood Metabolites, Antioxidant Status, Immune Response, and Testicular Gene Expression in Hu Sheep. Animals. 9(10):720-728.

Khan, A. and D. Konwar. 2015. Effect of Ascorbic Acid Supplementation on Physiological and Blood Biochemical Parameters in Goats during Summer. Anim. Nutr. Technology. 15(1):137-143.

McManus, C., B.S.L. Dallago, C. Lehugeur, L.A. Ribeiro, P. Hermuche, R.F. Guimarães, O.A.C. Júnior, and S.R. Paiva. 2016. Patterns of heat tolerance in different sheep breeds in Brazil. Small Rumin. Res. 144:290-299.

Okourwa, M. I. 2015. Effect of Coat Characteristics on Physiological Traits and Heat Tolerance of West African Dwarf Sheep in Southern Nigeria. Open J. Anim. Sci. 05(4):351-357.

Piccione, G., F. Fazio, S. Casella, P. Pennisi, and G. Caola, G. 2011. Influence of shearing on oxidative stress and some physiological parameters in ewes. Anim. Sci. J. 823):481485.

Seixas, L., C.B. De Melo, C.B. Tanure, V. Peripolli, and C. McManus. 2017. Heat tolerance in Brazilian hair sheep. Asianaustralas. J. Anim. Sci. 30(4):593-601.

Sejian, V., A.K. Singh, A. Sahoo, and S.M.K. Naqvi. 2014. Effect of mineral mixture and antioxidant supplementation on growth, reproductive performance and adaptive capability of Malpura ewes subjected to heat stress. J. Anim. Physiol. Anim. Nutr. 98(1):72-83.

Sejian, V., V.P. Maurya, and S.M.K. Naqvi. 2010. Adaptability and growth of Malpura ewes subjected to thermal and nutritional stress. Trop. Anim. Health Prod. 42(8):1763-1770.

Shaji, S., V. Sejian, M. Bagath, G.B. Manjunathareddy, E.K. Kurien, G. Varma, and R. Bhatta. 2017. Summer season related heat and nutritional stresses on the adaptive capability of goats based on blood biochemical response and hepatic HSP70 gene expression. Biol. Rhythm Res. 48(1):65-83.

Silanikove, N. 2000. Effects of heat stress on the welfare of extensively managed domestic ruminants. Livest. Prod. Sci. 67(1):1-18.

Singh, K. M., S. Singh, I. Ganguly, A. Ganguly, R.K. Nachiappan, A. Chopra, and K. Narula. 2016. Evaluation of Indian sheep breeds of arid zone under heat stress condition. Small Rum. Res. 141:113-117.

Steel, R.G.D and J.H. Torrie. 1997. Principles and Procedures of Statistics: A Biometrical Approach. McGraw-Hill.

Taha, E., A. Abdel-Khalek, W. Khalil, and A. N. Abdel. 2018. Wool Production and Characteristics, Physiological and Haematological Parameters and Level of some Metabolic Hormones in Barki Ewes Shorn in Autumn as Alternative of Spring Shearing. J. Anim. Poult. Prod. 9(10):415422.

Vosooghi-Postindoz, V., A. Tahmasbi, A.A. Naserian, R. Valizade, and H. Ebrahimi. 2018. Effect of Water Deprivation and Drinking Saline Water on Performance, Blood Metabolites, Nutrient Digestibility, and Rumen Parameters in Baluchi Lambs. Iran. J. App. Anim. Sci. 8(3):445-456.

Wojtas, K., P. Cwynar, and R. Kołacz. 2014. Effect of thermal stress on physiological and blood parameters in merino sheep. Bull. Vet. Inst. Pulawy. 58(2):283-288. 